\title{
ロイブニングセミナー II
}

\section{前頭葉損傷による高次脳機能障害のみかた}

\author{
前 島 伸一郎 ${ }^{*}$ 大 沢 愛 子* 棚 橋 紀 夫 **
}

\begin{abstract}
要旨：かつてはSilent area と言われた前頭葉前野にも多くの脳機能が存在し，人が生きていくため に非常に大切な役割を果たすことが明らかとなってきた。前頭葉損傷では，失語症や半側空間無視 に加え, 記憶障害, 注意障害がみられる。また, 遂行機能障害に加え, 脱抑制や人格変化などの社 会的行動障害，発動性低下や無関心などの症状がみられる。前頭葉損傷を論じるためには，前頭葉 の機能解剖や病態生理を理解した上で，詳細な評価を行わねばならない。ただし前頭葉機能検査の 多くは，限局した前頭葉病変に特異的な検査ではなく，別の部位の損傷によっても低下がみられる こともあるので注意が必要である。適切な評価を行い，病状を正確に把握することは，患者が快適 な社会生活を送るための第一歩になると思われる。

(高次脳機能研究 $32 （ 1 ） ： 21 ～ 28 ， 2012$ )
\end{abstract}

Key Words : 前頭葉, 遂行機能障害, 記憶障害, 失語, 半側空間無視 frontal lobe, executive dysfunction, memory impairment, aphasia, unilateral spatial neglect

\section{はじめに}

前頭葉は両側大脳半球の中心溝より前方で, 頭 頂葉の前部，側頭葉の上前方に位置する。系統発 生学的にヒトでもっとも発達し, 個体発生的には もっとも遅く成熟する部位である。かつては, 脳 神経外科医（あるいは精神外科医）によって，前 頭葉前部を切除する手術（前頭葉切載術 prefrontal lobotomy/白質切載術 leucotomy）がしばしば行わ れ（古川 1996, 南光 2010), その後遺症としての 人格変化や知能低下，けいれん発作が出現するた め，重要な部位であることは着目されていたもの の, 前頭葉は後遺症の出にくい脳葉 (silent area) として扱われてきた。近年, 神経心理学的評価法 の普及や画像診断の発達に伴い, 高次脳機能障害 を論じる上で, 前頭葉の役割は欠かせなくなって いる。本稿では前頭葉損傷による高次脳機能障害 について概説を行う。

\section{I．前頭葉の解剖・生理}

前頭葉は大脳の中心溝より前方の領域である
(図 1)。一次運動野（area 4）は前頭葉外側面のも っとも後方に位置し, 中心溝を挟んで中心後回と 接する。その前方の運動前野 (area 6) とともに 運動の遂行や準備を行う。運動前野よりすぐ前で 中前頭回の後方部にある小領域は前頭眼野（area 8）と呼ばれ, 眼球運動を司る。これらの運動皮質 より前方に位置するのが，前頭連合野（前頭前野） である。前頭連合野は，行動計画に必要な情報を 側頭連合野や頭頂連合野から受け取り，複雑な行 動計画を組み立て, その実行の判断を行う。前頭 連合野は大きく, 前頭葉背外側と眼窩皮質, 帯状 皮質の 3 つに分けられ, 思考や創造性を担う。ま た, 優位半球の下前頭回後部（三角部と弁蓋部） は運動性言語中枢いわゆる Broca 野（area 44, 45) と呼ばれる。

\section{II. 前頭葉損傷の病態生理}

前頭葉は主に前大脳動脈と中大脳動脈によって 栄養される（後藤ら 1992）。いずれも, 内頸動脈 からの分枝であるが, 前大脳動脈は大脳縦裂の間 に入り，大脳の内側面を上方に向かい，内側線条

\footnotetext{
*埼玉医科大学国際医療センター リハビリテーション科％ 350-1298 埼玉県日高市山根 1397-1 **同 神経内科

受稿日 2012 年 1 月 30 日
} 


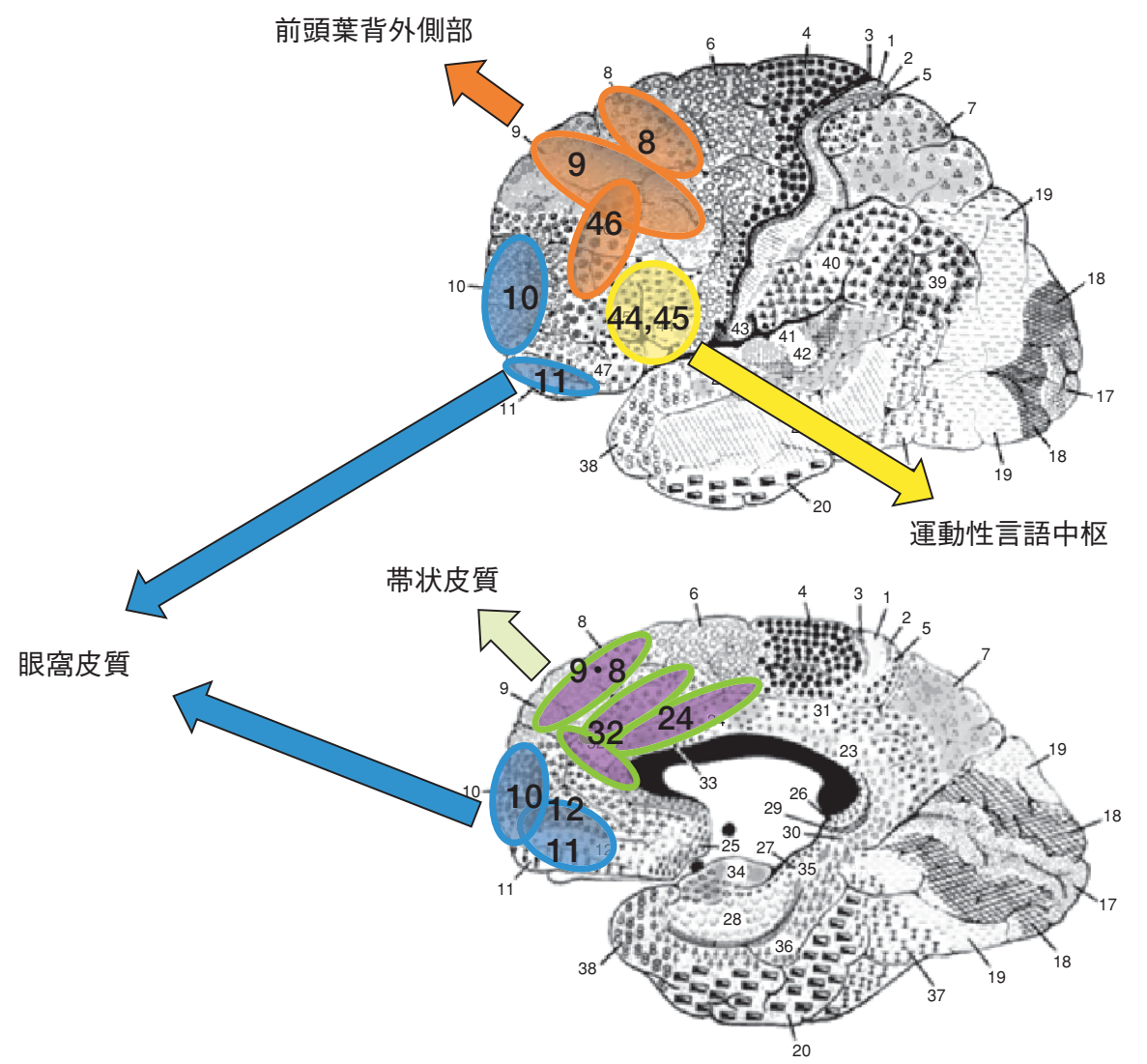

図 1 ブロードマンの脳地困と前頭葉

体動脈, 眼窩枝, 前頭極動脈, 脳梁辺縁動脈, 脳 梁周囲動脈などに分かれる。半球内側面に分布し， 前頭葉の内側面や底面の全域, 頭頂葉の内側面と 脳梁に血液を供給する。前大脳動脈が分岐した後, 中大脳動脈は側頭葉と島の間にある大脳外側窩に 入り, 大脳外側面を上後方へ向かう。主として半 球外側面に分布し, 前頭葉底面の外側部, 中, 下 前頭回, 中心前回の大部分, 頭頂葉, 側頭葉外側 面の大部分に血液を供給する。したがって，前頭 葉内側面，底面の全域は前大脳動脈が，前頭葉底 面の外側部，中，下前頭回，中心前回の大部分は 中大脳動脈からの血管支配をうける（図 2)。脳梗 塞では前大脳動脈や中大脳動脈など内頸動脈系の 梗塞がもっとも多く, 前頭葉に病変をきたす可能 性が高い。前交通動脈などの前大脳動脈系や内頸 動脈, 中大脳動脈は脳動脈瘤の好発部位であり,
種々の合併症によって前頭葉損傷をきたすことも 少なくない。一方，頭部を激しく打撲すると，直 下には陽圧による直撃損傷（Coup-injury）が発生 し，反対側では陰圧を生じて骨と脳の間が空洞化， 気胞の形成と崩壊により反衝損傷 (Contrecoup injury）が発生する（Courville 1942, Holbourn 1943）。前頭部に外力が作用した場合には、受傷直 下の前頭葉に直撃損傷が生じることが多い。一方， 後頭部に外力が作用した場合には、受傷直下に直 撃損傷が生じることは少なく、反衝損傷によって 前頭葉に挫傷が生じやすい。そのため，頭部外傷 では前頭葉損傷をきたす可能性が高い。

\section{III. 前頭葉病変による症候}

\section{1. 前頭葉と失語症}

失語症は大まかに流暢型，非流暢型に分けられ 

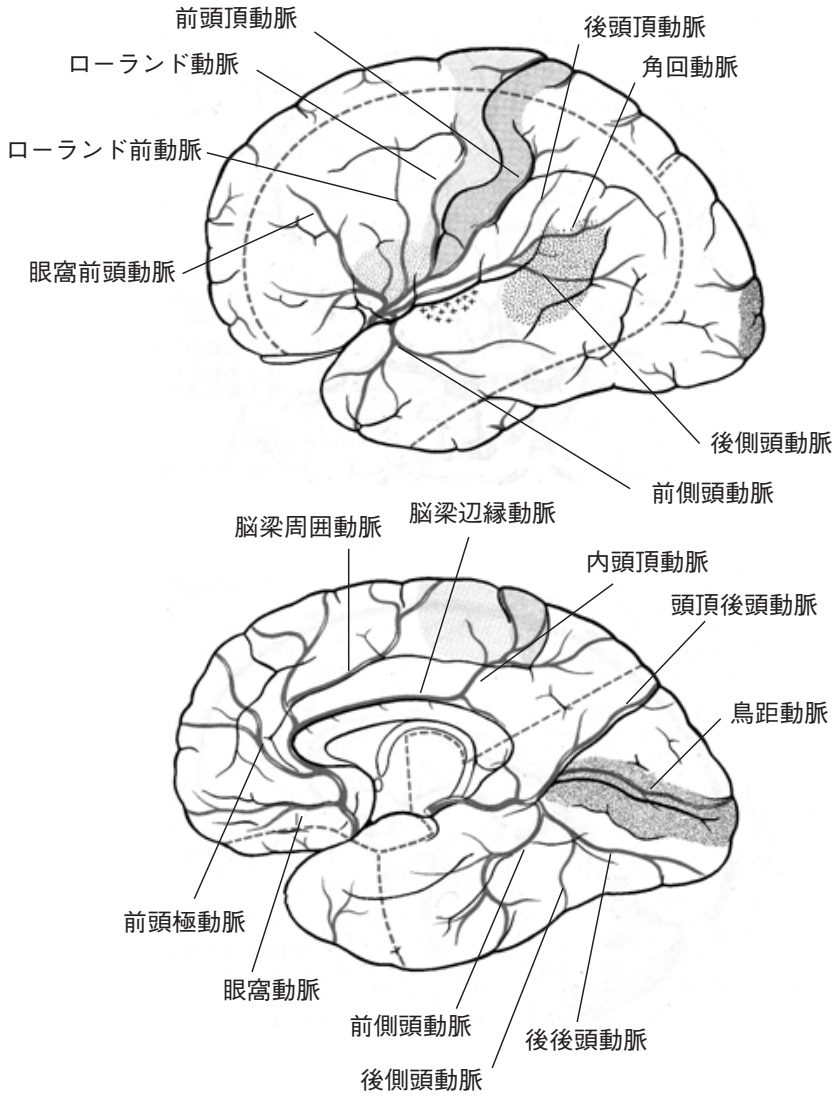

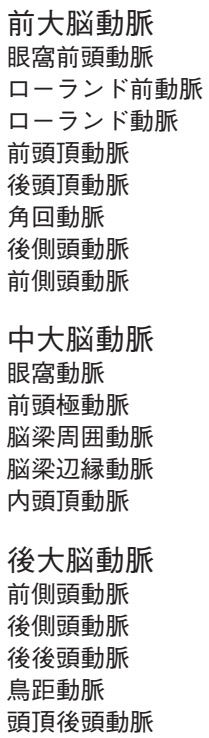

図 2 前, 中, 後大脳動脈の分枝と支配領域
る。流暢性を規定する因子は, 句の長さ, プロソ ディー (韻律), 会話の速度, 努力性, 休止, 構音 の歪みなどである (Benson 1979)。一般に，左前 頭葉損傷では，運動性失語に代表される非流暢型 の失語が出現するとされてきた（榎戸ら 1988，田 邊ら 1982)。すなわち，アナルトリー (失構音) と喚語困難を要件とする Broca 失語や, 自発言語 の障害に比して復唱の保たれる超皮質性運動失語 などがその代表的なタイプである。近年，相馬ら （1994）や大柣（2008）らの詳細な病巣研究によっ て, 失語症では, 要素的な症状の集まりが, それ ぞれの失語症タイプを形成すると考えられている。 典型的な Broca 失語は中心前回の損傷を認めるた め, 失構音（アナルトリー）の特徽である構音の 歪みやプロソディの障害，さらに音韻性錯語など を伴う。しかし，Broca 野近傍に限局した損傷で
あっても, 発話に失構音（アナルトリー）を認め ず，喚語困難と文の理解障害がみられることもあ り，このような失語症は「Broca 領域失語」(相馬 ら 1994）と呼ばれる。

\section{2. 前頭葉と半側空間無視}

半側空間無視は, 要素的感覚障害や運動障害が ないにもかかわらず，病巣と反対側からの種々の 刺激や状況に気付かず反応しない状態をいう (Heilman 1993)。一般に右大脳半球の頭頂後頭葉 接合部の病変で生じるとされているが，前頭葉の 病変で生じることも知られている。半側空間無視 の評価として BIT 行動性無視検查日本版（石合ら 1999）がよく使われる。これは通常検查と行動検 查からなり, 半側空間無視の定量的評価のみなら ず，誤反応や反応時間を分析することで，その質 的な評価も可能と考えられている（御園生ら 
2001)。前頭葉病変による半側空間無視は軽度で予 後良好なものが多いとされてきたが, 運動探索課 題で異常をきたしやすく, 質的にも違いがみられ る可能性がある（Maeshima ら 1997）。

\section{3. 前頭葉と記憶障害}

前頭葉底部の脳動静脈奇形や前交通動脈の脳動 脈瘤破裂によるくも膜下出血の術後に記憶障害が みられることがあり, 前脳基底部健忘と呼ばれる。 前脳基底部は, 外側, 内側の中隔核, Broca三角 带, Meynert 基底核などからなる領域で, 大脳皮 質や海馬，扁桃体に投射してその局所脳血流を調 節するコリン作動性ニューロンが存在する。この 領域は, 前大脳動脈あるいは前交通動脈からの穿 通動脈によって灌流される。前交通動脈からの穿 通枝は, 平均 4.1 本の穿通枝があり, この中でも, 両側の梁下野を灌流する枝（subcallosal branch） は，記憶障害に関係するとされている。また，前 脳基底部のみならず，眼窩部（緑川ら 1999）や穹 隆部（半田 1989）, 線条体の損傷 (Irle ら 1992) が重篤な記憶障害を引き起こすと報告されている。

前脳基底部病変による記憶障害は, 通常の記憶 障害に加え, 人格変化や激しい作話, それに前頭 葉性の障害が加わることが特徵的である（船山 2011）。Damasio ら（1985）は「名前や顔など個別 の情報を覚えることはできるが，これらを関連の ある事柄として想起することができず，時間的配 列ができないのが特徴である」と述べた。しかし 実際は，「他の部位よる健忘と質的な違いは認めな い」という見解や, 随伴する前頭葉症状の影響, 前脳基底部以外の病変の広がりなどを加味して検 討する必要がある。くも膜下出血の場合は，それ 自身による濔漫性の障害や脳内血腫, 手術による 侵襲，脳血管攣縮，水頭症の影響など多くの要因 が関与する。とくに, 破裂前交通動脈瘤術後では 内頸動脈や中大脳動脈系の脳動脈瘤に比べ, 遂行 機能障害や注意障害を伴い, 記憶障害に影響を及 ぼすため，これらの機能を合わせて評価していく ベきである。

\section{4. 前頭葉と行動障害}

前頭葉損傷でみられる行動障害として, 遂行機 能障害に加え, 脱抑制や人格変化などの社会的行 動障害, 発動性低下や無関心などがある。遂行機
能障害は, 行動の開始困難や自発性の減退, 認知 ないしは行動の転換障害, すなわち保続や固執, 行動の維持困難や行為の中断, 行為の中止困難, 衝動性や脱抑制，誤りの修正障害などによって引 き起こされるが, 遂行機能そのものの障害という ためには, 注意やエピソード記憶, 空間認知, 知 能などの基盤となる認知機能が保たれていること が重要である。遂行機能は広義の前頭葉機能に含 まれるが，前頭葉の損傷だけで生じるわけではな く, 脳のどの部位がやられても遂行課題が低下す ることを理解しておく必要がある。また，脱抑制 があると，思ったことをそのまま言ったり，行動 したりするため, 相手を傷つけたり, 気分を害し たりしてしまうことがあり，集団のなかで適応し た生活を送ることが難しくなることがある（三村 2008）。この障害は, 自分の言動を相手がどう思う かを理解できない問題と衝動コントロールの問題 が複合的に関与している。また，意思決定ができ なくなり，目先の報酬に引きずられてしまう。発 動性低下がみられ，何ごとに対しても無気力・無 関心となることがある。Cummings（1993）は前 頭葉・皮質下に, 線状体や淡蒼球, 視床を結ぶ 3 つの回路を提唱した。前頭葉外側穹隆部（背外側 面）の損傷では, 遂行機能障害に加え, 転換障害, 保続が生じ, 前頭葉眼窩面の損傷では脱抑制, 带 状回前部の損傷では発動性低下が引き起こされる と考えられている（Tekinら 2002）。ただし，行 動変化の特徴には個人差が大きく, 実際に症例を 検討しても, さまざまな障害が混在し, 行動変化 のパターンを予測することは困難である（村井 2009)。

\section{IV. 前頭葉機能を評価する神経心理学的検査}

このような前頭葉機能障害を正しく評価するた めに, 神経心理学的検査を用いて, 患者の障害さ れた側面をうまく捉えていかなくてはならない (表 1)。前頭前野の局所的損傷では, 発動性の低 下や常同行為，保続，思考障害，社会行動障害な どさまざまな症状がみられるが（Damasioら 1993), 従来の知能検査では成績低下がみられない ことも少なくない。したがって，障害を正確に捉 えるためには, 記憶や注意, 遂行機能, 社会行動 
表 1 前頭葉機能障害とその検査法

\begin{tabular}{|c|c|c|}
\hline 障害される側面 & 症状 & 検査法の例 \\
\hline 保続と反応抑制 & ステレオタイプの抑制障害 & go-no go 課題, 継次的運動課題 \\
\hline \multirow[t]{2}{*}{ 概念の転換 } & 心の構え (心的セット) の切り換え困難 & ウィスコンシンカード分類検査 \\
\hline & 柔軟性の低下 & ストループテスト \\
\hline \multirow[t]{3}{*}{ 流暢性 } & 語想起の障害 & 語頭音による語の産生（列挙） \\
\hline & 図形想起の障害 & 図形描画 \\
\hline & 発想の貧困化 & 物品用途テスト \\
\hline \multirow[t]{2}{*}{ 注意 } & 注意の分配・転換の障害 & トレイルメーキングテスト B \\
\hline & $\begin{array}{l}\text { ワーキングメモリー } \\
\text { (保持と処理を同時に行うことの障害) }\end{array}$ & $\begin{array}{l}\text { 定速聴覚的連続加算テスト (PASAT), } \\
\text { 乱数生成 memory updating, リーディン } \\
\text { グスパンテスト, 二重課題 }\end{array}$ \\
\hline \multirow[t]{3}{*}{ 記憶 } & 展望記憶の障害 & リバミード行動記憶検査 \\
\hline & 記憶の組織化の障害 & $\begin{array}{l}\text { レイの } 15 \text { 語記銘検査 } \\
\text { レイ-オステルリート複雑図形 }\end{array}$ \\
\hline & 時間順序に関する記憶の障害 & 親近性テスト \\
\hline 人格 & $\begin{array}{l}\text { 発動性や意欲の低下 · 無関心 ・無感情・易疲 } \\
\text { 労性・うつ状態・気づき (アウェアネス)の低下 }\end{array}$ & \\
\hline
\end{tabular}

(三村 將: 遂行機能. よくわかる失語症と高次脳機能障害 (鹿島晴雄, 種村 純, 編)。永井書店, 大阪, 2003, p.388より許 諾を得て転載)

などを評価する必要がある。簡便な記憶の検査と

して Auditory Verbal Learning Test (AVLT) や ReyOsterrieth の複雑図形（ROCFT）などがあるが (Rey 1941，1964），課題に対する方略を評価する ことにより前頭葉機能としての記憶の組織化（三 村 2000) をみることができる。日本版リバミード 行動記憶検查 (Rivermead Behavioural Memory Test；RBMT）は単に記銘力を評価するのではな く，展望的記憶を含む日常生活に準拠した記憶を 評価できる（数井ら 2002）。注意障害には, Paced auditory serial addition task (PASAT) や Audio motor method な゙が用いられるが，これらは，日 本高次脳機能障害学会で発売された標準注意検査 法（CATS）に含まれている（加藤 2006）。

Wisconsin Card Sorting Test (WCST) や Stroop Test, Trail Making Test (TMT), 言語流暢性検査 は注意・概念の転換や思考の柔軟性を反映する
（鹿島 2007）。Frontal Assessment Battery （FAB） は, 類似性, 語の流暢性, 運動系列, 葛藤指示, GO-NO-GO 課題, 把握行動など前頭葉機能の諸 要素を多面的にスクリーニングするために考案さ れたもので, 特別な器具を必要とせず, ベッドサ イドでも簡便に行える (Duboisら 2000)。遂行機 能障害症候群の行動評価法 (Behavioural Assessment of the Dysexecutive Syndrome ; BADS）は実生活の活動に類似した 6 種類の下位 検査と 1 つ質問表から構成されており, さまざ まな行動面の障害を系統的かつ包括的に評価する (田渕ら 2004)。単一の検査では遂行機能全体を評 価することが難しいため, 複数の検査を組み合わ せなければ全体の障害像が浮かび上がってこない 場合には有用な検査である。いずれも前頭葉機能 を評価する検査法ではあるが，限局した前頭葉病 変に特異的な検査ではなく, 他の部位の脳損傷に 
よっても成績が低下するので注意が必要である。

また，これらは主に前頭前野の背外側部の機能 障害を評価する検査法であるが，前頭葉眼窩部・ 腹内側部の損傷でみられる社会的行動障害や意思 決定の障害は評価できない（三村 2009）。自らの 行動選択の将来における帰結を評価し, 適切な行 動の選択方法を学習できるかどうかを検討するた めに, ギャンブリング課題が用いられる（Bechara ら 2000)。また, 多幸症, 無感情などの人格変化 や社会行動の障害には, 個々の症状を詳細に捉え る必要がある。Neuropsychiatric Inventory (NPI) は, 患者の行動をよく知っている介護者のインタ ビューに基づいて行う観察式の評価尺度であり, 妄想, 幻覚, 興奮, 不安, うつ, 多幸, 無為, 脱 抑制, 易刺激性，異常行動の10 項目についてそれ ぞれ得点化される（博野ら 1997）。Frontal Behavioral Inventory（FBI）は主に前頭側頭型認知 症の示す認知行動障害を臨床的に検出するための 簡便な介護者による自記式の質問紙として開発さ れたが, 局在性前頭葉損傷を有する患者の行動障 害の検出にも有用とされている（松井ら 2008）。 やる気スコアは, 新しいことを学びたいか, 何か 興味を持っていることがあるか等の 14 項目につい て得点化し, 16 点以上をやる気低下と判定する (岡田ら 1998)。

\section{おわりに}

かつては Silent area と言われた前頭葉にも多く の機能が存在し, 人が生きていくために非常に大 切な役割を果たすことが明らかとなってきた。前 頭葉機能を適切に評価し, 病状を正確に把握する ことが，患者の快適な社会生活の実現に寄与する ものと思われる。

\section{文献}

1) Bechara, A., Damasio, H. \& Damasio, A. R. : Emotion, Decision Making and the Orbitofrontal CortexCereb. Cortex, 10 : 295-307, 2000.

2 ) Benson, D. F. : Aphasia, alexia and agraphia. Churchill Livingstone, New York, 1979.
3 ) Brodmann, K. : Vergleichende Lokalisationslehre der Grosshirnrinde. Leipzig : Johann Ambrosius Bart, 1909.

4 ) Courville, C. B. : Coup-contrecoup mechanism of craniocerebral injuries : some observations. Arch. Surg., 54 : 19-43, 1942.

5 ) Cummings, J. L. : Frontal-subcortical circuits and human behavior. Arch. Neurol., 50 : 873880, 1993.

6 ) Damasio, A. R., Graff-Radford, N. R., Eslinger, P. J., et al. : Amnesia following basal forebrain lesions. Arch. Neurol., 42 : 263-271, 1985.

7 ) Damasio, A. R. \& Anderson, S. W. : The frontal lobes. Clinical Neuropsychology (eds Heilman, K. M. \& Valenstein, E.). 3rd Ed., Oxford University Press, New York, 1993, pp. 409-460.

8 ) Dubois, B., Slachevsky, A., Litvan, I., et al. : The FAB : A frontal assessment battery at the bedside. Neurology, 55 : 1621-1626, 2000.

9 ) 榎戸秀昭, 鳥居方策, 鈴木重忠, ほか：前方失 語と前ローランド動脈。神経心理学, 4：125132, 1988.

10）船山道隆：記憶障害の神経基盤 前脳基底部損傷 による健忘。高次脳機能研究, 31：301-310, 2011.

11）古川哲雄：ロボトミー。神経内科, 45：170174, 1996.

12）後藤文男, 天野隆弘：臨床のための神経機能解 剖学. 中外医学社, 東京, 1992.

13) Heilman, K. M. : Neglect and related disorders. In : Clinical Neuropsychology (eds Heilman, K. M. \& Valenstein, E.). 3rd Ed., Oxford University Press, Oxford, 1993, pp. 279-336.

14）半田貴士：前頭葉性記憶障害の神経心理学的研 究. 慶應医学, 66 : 153-166, 1989.

15）博野信次, 森 悦朗, 池尻義隆, ほか：日本語 版 Neuropsychiatric Inventory：痴朵の精神症状 評価法の有用性の検討. 脳と神経, $49 ： 266-271$, 1997. 
2012 年 3 月 31 日

16）平岡千穂, 前島伸一郎, 大沢愛子, ほか：Broca 失語と Broca 領域失語：異なる失語症タイプを呈 した左前頭葉出血の 2 症例。Neurological Surgery, 37 : 987-993, 2009.

17) Holbourn, A. H. S. : Mechanism of head injuries. Lancet, 2 : 438-441, 1943.

18）石合純夫：BIT 行動性無視検査日本版。新興医 学出版社, 東京, 1999.

19) Irle, E., Wowra, B., Kunert, H. J., et al. : Memory disturbances following anterior communicating artery rupture. Ann. Neurol., $31 ：$ 473-480, 1992.

20）加藤元一郎, 注意 - 意欲評価法作製小委員会 : 標準注意検査法 (CAT) と標準意欲評価法 (CAS) の開発とその経過. 高次脳機能研究, 26:310319, 2006.

21）鹿島晴雄 : 認知症の神経心理学的検査一神経心 理学的検査の問題点について. 老年精神医学雑 誌, 18 (臨増)：51-57, 2007.

22）数井裕光, 綿森淑子, 本多留実, ほか：日本版 リバミード行動記憶検査（RBMT）の有用性の検 討。神経進歩，46：307-317, 2002.

23) Maeshima, S., Truman, G., Smith, D. S., et al. : Is unilateral spatial neglect a single phenomenon? ; A comparative study between exploratory - motor and visual - counting tests. J. Neurol., 244 : 412417, 1997.

24）松井三枝, 三村 將, 田㴊肇, ほか：日本版 前頭葉性行動質問紙 Frontal Behavioral Inventory (FBI) の作成. 高次脳機能研究, $28 ： 373-382$, 2008.

25）緑川 晶, 塩田純一, 河村 満：前脳基底部病 変による健忘と時間的順序の記憶. 失語症研究, 19 : 245-251, 1999.

26）御園生香, 石合純夫, 小山康正, ほか：BIT 日 本版通常検査における右半球損傷患者の誤反応 分布一Laterality indexによる検討一，神経心理 学, $17: 121-129,2001$.

27）三村 將：前頭葉機能をめぐる神経心理学の controversies 一前頭葉と記憶との関連をめぐっ
(27) 27

て一. 神経心理学, $16: 171-178,2000$.

28）三村 將：遂行機能. よくわかる失語症と高次 脳機能障害 (鹿島晴雄, 種村 純, 編). 永井書 店，大阪，2003, pp. 388-395.

29）三村 將：前頭葉と精神症状に対するアプロー 千. 高次脳機能研究, $28 ： 257-266,2008$.

30）三村 將：社会的行動障害への介入法一精神医 学的観点からの整理一. 高次脳機能研究, 29 : 26-33, 2009.

31）村井俊哉：社会的行動障害の症候学. 高次脳機 能研究, $29 ： 18-25,2009$.

32) 南光進一郎：エガス・モニスとノーベル賞（後 編). 帝京医学雑誌, 33：67-74, 2010.

33）大㭇美佳：高次脳機能障害 失語症 失語症の 定義とタイプ分類. 神経内科, 6 (suppl 5)：155165, 2008.

34）岡田和悟, 小林祥泰, 青木 耕, ほか：やる気 スコアを用いた脳卒中後の意欲低下の評価。脳 卒中, 20 : 318-323, 1998.

35) Rey, A. : L'examen clinique en Psychogie. Presses Universitaires de France, Paris, 1964.

36) Rey, A. : Lexamen psychologique : Dans les cas d'encephalopathie traumatique (Les problemes). Arch. Psychol., 28 : 286-340, 1941.

37）相馬芳明, 大槻美佳, 吉村菜穂子, ほか：Broca 領域損傷による流暢性失語. 神経内科, 41：385391, 1994.

38）田㴊 肇，鹿島晴雄：遂行機能障害の評価法. 臨床リハ別冊／高次脳機能障害のリハビリテー ションVer. 2（江藤文夫, 武田克彦, 原 寛美, 編)。医柬薬出版，東京，2004, pp. 176-181.

39）田邊敬貴, 大東祥孝：Broca 領野と Broca 失語. 脳と神経, $37 ： 797-804,1982$.

40) Tekin, S. \& Cummings, J. L. : Frontal-subcortical neuronal circuits and clinical neuropsychiatry ; an update. J. Psychom. Res., 53 : 647-654, 2002.

41）山鳥 重：失語の分類とその実際：古典分類と Geschwind 派の分類. 神経進歩, 21：869-877, 1977. 
Abstract

\section{Assessment of cognitive impairment due to frontal lobe damage}

\section{Shinichiro Maeshima* Aiko Osawa* Norio Tanahashi**}

The prefrontal area has been once called "Silent area". However, in recent years, it has known that there are many cognitive function in the prefrontal area and it plays a very important role in order to make a living in the society for human. The damage of frontal lobe causes aphasia, unilateral spatial neglect, memory disorder, and disturbance of attention. Moreover, an execution functional disorder, social behavior disorders such as disinhibition and a personality change, and apathy are seen. In order to exam the patients with frontal lobe damage, we have to evaluate neuropsychological and psychological function in detail, based on functional anatomy and pathophysiology. The abnormality in the neuropsychological tests for the frontal lobe function does not reflect only the damage of frontal lobe specifically and the abnormal results may also cause from the damage of other part in the brain. To conduct a correct evaluation and diagnosing pathophysiology is the first step for a patient with frontal lobe damage to lead comfortable social life.

\footnotetext{
* Department of Rehabilitation Medicine, Saitama Medical University International Medical Center.

1397-1 Yamane, Hidaka-shi, Saitama 350-1298, Japan

** Department of Neurology, Saitama Medical University International Medical Center
} 